\title{
PERAN PEMERINTAH DALAM OPTIMALISASI TANAH WAKAF
}

\author{
Oleh : \\ Jauhar Faradis, Awis Hardjito, Ipuk Widayanti \\ Jauhar f1@yahoo.com
}

\begin{abstract}
ملخص
إنما يستفاد أراضي الوقف في إندونيسيا لبناء المساجد، المدارس وغيرها من الحوائج الاستهلاكية. تأخر ترقيّ أمثل تنمية أرض الوقف في إندونيسيا من أسباهما قلة رأس المال و قلة اهتمام الحكومة بالأوقاف. إصدار صكوك الحكومة الشرعية بعقد الإجارة من نموذج وبنيان أمثل تنمية أرض الوقف، ويحتاج إلى اشتراك الحكومة، وناظر الوقف والشعب. فيكون بين الحكومة و ناظر الوقف عقد الإجارة وكذلك بين الحكومة والشعب (زبون صكوك الحكومة الشرعية). يقوم هذا البحث بتحليل جدوى الاستمار باستخدام منهاج تحليل الموازنة الرأسمالية مثل صافي القيمة الحالية (Net Present Value (NPV))، و معدل العائد الداخلي (Internal Rate of (IRR) Return () PI ) من تحليل جدوى الرأسمالية. فالخلاصة أن الاستثمار بالمناهج المذكورة يمكن بل يستحق تطبيقها. أما ريعة استثمارها فستحصل بعد ثلاثين عاما. استفادت الحكومة أو الشركة الحكومية من إصدار هذه الصكوك بحصول رأس المال، ونيل الأرباح من المشروعات التنمية الوقفية، وصنع الأسواق المالية. واستفاد الناظر و هيئة الأوقاف الإندونيسية بكصول ريعات المشروعات الوقفية ونيل ثمن الإجارة من الأراضي الوقفية. وبعد انتهاء عقد الإجارة على الأراضي الوقفية، يملك الناظر الممتلكة المبنية على الأراضي الوقفية فأصبحت الممتلكة مال الوقف يهدف لرفع رفاهية المجتمع. فأدرك الوقف غايته بتحقيق النفع اجتماعيا واقتصاديا. مفتاح الكلمات:الوقف، صكوك الحكومة الشرعية، متلكة الإجارة المجارة، تحليل الموازنة الرأسمالية
\end{abstract}

Abstract

The use of waqf land in Indonesia is currently only used for the construction of mosques, education and other consumptive needs. The obstacle in utilizing waqf land in Indonesia is a lack of capital due to a lack of government interference. With the Ijarah Assets to be Leased SBSN scheme as a means of optimizing waqf land, this concept involves the Government, Nazhir and Consumers where the contract of transactions between the Government and Nazhir is carried out with an Ijarah contract (rent), as well as Government contracts with Consumers in the form of Ijarah contract (rent). This study analyzes investment feasibility using the capital budgeting analysis method such as NPV, IRR, and PI in the analysis of capital feasibility. the conclusion is that the investment made is feasible. The value of the profits obtained for 30 years is already present in value, so it is not much different from 30 years in the future.

For the Government/BUMN, the benefits obtained in the form of profits from sukuk issuance, get a portion of the proceeds from the proceeds project, and act as a market maker. For Nazhir and BWI, they will get compensation from the proceeds of the project and rental income on the waqf land. After the lease period expires Nazhir gets assets that have been built on waqf land. Nazhir can produce other waqf assets so that they can produce new waqf to prosper the community and the wider community, will reap economic and social benefits

Key Words: waqf, SBSN, Ijarah Assets to be Leased, capital budgeting analysis. 
Abstrak

Berdasarkan Perjanjian Build Operate and Transfer (BOT) merupakan perjanjian baru yang tidak dikenal sebelumnya di dalam hukum perjanjian Indonesia. BOT tidak diatur secara jelas di dalam Buku III KUHPerdata sehingga dapat dikatakan sebagi perjanjian tidak bernama. Di beberapa negara yang pengelolaan wakafnya sudah maju, seperti Singapura, Malaysia, Mesir, dan lain-lain, pengelolaan aset tanah wakaf produktif dilakukan dengan membangun infrastruktur yang bernilai ekonomi tinggi melalui perjanjian BOT. Berdasarkan Undang-undang Nomor. 41 Tahun 2004 Tentang Wakaf, pengelolaan wakaf diarahkan kepada pengelolaan yang produktif termasuk hak atas tanah berupa HGB yang secara khusus diatur dengan Peraturan Pemerintah Nomor. 42 Tahun 2006 tentang Pelaksanaan Undang-undang Wakaf. HGB dapat diwakafkan baik untuk selamanya maupun untuk sementara waktu. HGB yang diwakafkan sementara, dan dikelola oleh nazhir melalui perjanjian BOT dapat menimbulkan masalah hukum, terutama mengenai status perjanjian dan perlindungan hukum investor, khususnya ketika wakaf HGB itu berakhir lebih dulu daripada perjanjian BOT.

Penelitian ini dilakukan dengan menggunakan pendekatan yuridis normatif, dengan melakukan kajian terhadap beberapa peraturan perundang-undangan, dan melakukan wawancara terhadap BWI, BPN dan MUI untuk mendapatkan keterangan secara nyata mengenai wakaf produktif.

Dalam kasus ini, setelah dilakukan penelitian penulis menyimpulkan bahwa maka status perjanjian BOT atas tanah wakaf HGB yang sudah berakhir masa berlakunya dapat dianggap batal karena hilangnya kewenangan nazhir sebagai pihak pengelola wakaf, akan tetapi perjanjian BOT tetap dapat dilangsungkan dengan dibuatnya addendum yang mengatur bahwa nazhir sebagai pihak dalam perjanjian BOT kemudian digantikan dengan pihak pemegang hak atas tanah HGB dengan konsekuensi hak nazhir yang berupa bagi hasil pengelolaan infrastruktur selama sisa waktu perjanjian serta kepemilikan infrastruktur setelah masa perjanjian BOT berakhir, menjadi milik pemegang hak atas tanah kecuali ditentukan lain dalam addendum. Sebagai bentuk perlindungan hukum bagi investor, investor tetap dapat mengelola infrastruktur berikut segala manfaat ekonominya sampai dengan waktu yang ditentukan. Apabila terjadi kerugian bagi investor dan kesalahan nazhir dapat dibuktikan, berdasarkan prinsip tanggungjawab berdasarkan atas kesalahan, maka investor dapat meminta ganti rugi, apabila tidak terbukti ada kesalahan, maka kerugian ditanggung investor sendiri.

Kata Kunci: BOT, Wakaf, HGB, Nazhir, Addendum

\section{A. Pendahuluan}

Wakaf merupakan salah satu lembaga sosial Islam yang sangat dianjurkan dalam ajaran Islam untuk dipergunakan oleh seseorang sebagai sarana penyaluran rezeki yang diberikan oleh Allah kepadanya (Nasution dan Hasanah, 2005). Wakaf juga salah satu instrumen untuk menciptakan keadilan dan kesejahteraan dalam bidang ekonomi. Ciri utama wakaf adalah ketika wakaf telah ditunaikan terjadi pergeseran kepemilikan dari pemiliknya pibadi menuju kepemilikan masyarakat muslim yang diharapkan abadi dan memberikan manfaat yang berkelanjutan. Melalui wakaf diharapkan terjadi proses distribusi manfaat bagi masyarakat secara luas, dari manfaat pribadi menuju masyarakat manfaat (Esposito, 2001).
Wakaf dalam syariah Islam sebenarnya mirip dengan sebuah economic corporation di mana terdapat modal untuk dikembangkan yang keuntungannya digunakan bagikepentingan umat. Yang lebih menjamin keabadian wakaf itu adalah adanya ketentuan tidak boleh menjual atau mengubah aset itu menjadi barang konsumtif, tetapi tetap terus menjadikannya sebagai aset produktif. Dengan kata lain, paling tidak secara teoritis, wakaf harus selalu berkembang dan bahkan bertambah menjadi wakaf-wakaf baru (Nafis, 2010).

Menurut data yang dihimpun oleh Kementrian Agama RI tahun 2016 tanah wakaf di Indonesia berjumlah 435.768 lokasi dengan total luas 4.359.443.170 meter persegi atau 
435.944,31 hektar. Adapun nazhir wakaf belum banyak mengelola secara profesional, karena kebanyakan nazhir wakaf hanya kerja sampingan. Hasil penelitian Pusat Bahasa dan Budaya (PBB) UIN Syarif Hidayatullah Jakarta, tahun 2006, terhadap 500 responden nazhir di 11 Propinsi, menunjukkan bahwa harta wakaf lebih banyak bersifat diam (77\%) daripada yang menghasilkan atau produktif (23\%). Temuan umum lainnya juga menunjukkan pemanfaatan terbesar harta wakaf adalah masjid (79\%) daripada peruntukkan lainnya, dan lebih banyak berada di wilayah pedesaan (59\%) (Nafis, 2010).

Hasanah (2005) menjelaskan bahwa salah satu kendala yang mendasar dalam pengelolaan wakaf di Indonesia adalah kemampuan nadzir wakaf yang sangat minim sekali dan masih bersifat tradisional, baik yang bertkaitan dengan aspek pemahaman terhadap wakaf itu sendiri maupun aspek keterampilan dalam menjalankan roda kenazdiran. Ditinjau dari aspek pemahaman, pada umumnya umat Islam di Indonesia termasuk para nazdir masih banyak yang memahami bahwa wakaf itu hanya berupa harta benda yang tidak bergerak saja, seperti tanah atau berupa suatu bangunan. Padahal untuk mengelola harta benda tidak bergerak diperlukan wakaf benda bergerak seperti misalnya uang, saham dan lain-lain.

Banyaknya tanah wakaf yang belum termanfaatkan dengan baik dan masih diam tersebut disebabkan oleh beberapa kendala, salah satu kendala adalah faktor modal uang untuk mengoptimalkan tanah wakaf. Oleh karena itu perlu adanya peran pemerintah untuk mengoptimalkan tanah wakaf. Sesuai dengan pasal 33 ayat 3 Undang-undang Dasar (UUD) 1945 yang menyatakan bahwa "bumi, air dan kekayaan alam yang terkandung di dalamnya dikuasai oleh Negara dan dipergunakan sebesar-besarnya untuk kemakmuran rakyat." Berdasarkan undangundang tersebut pemerintah memiliki peran yang sangat besar dalam menguasai tanah air NKRI dan mengupayakan kesejahteraan rakyat Indonesia.
Salah satu cara pemerintah dalam mengupayakan kesejahteraan rakyat dengan memanfaatkan tanah sebagai aset negara adalah dengan mengoptimalkan tanah wakaf. Namun dalam mengoptimalkan tanah wakaf tersebut pemerintah membutuhkan modal. Salah satu instrumen dalam mendapatkan modal adalah penerbitan surat utang negara berbasis syariah (SBSN).

Skema SBSN sangat memungkinkan pengumpulan dana untuk melakukan pembangunan di atas tanah wakaf, dengan tujuan mengoptimalkan tanah tersebut. Dengan menggunakan skema SBSN penelitian ini bertujuan mengkaji dari segi aspek ekonomi dan sosial baik untuk pemerintah (BUMN) maupun Nazhir.

\section{Wakaf}

Wakaf secara etimologi adalah al habs (menahan), al-man-u (menghalangi) (anshari, 2000, Salabi, 1957). Wakaf berasal dari kata kerja yaitu waqafa, yaqifu, waqfan yang berarti berhenti, berdiam ditempat atau menahan (Warson, 1989). Pengertian wakaf menurut ulama terjadi perbedaan pendapat. Perbedaan ini berimplikasi pada status tanah wakaf dan akibat yang muncul dari harta wakaf.

Pertama, ulama hanafi medefinisikan wakaf sebagai menahan benda milik orang yang berwakaf dan menyedekahkan manfaatnya untuk kebaikan baik untuk sekarang atau masa yang akan datang (al-Ainaini). Kedua, ulama Malikiyah wakaf merupakan waqif menjadikan manfaat harta yang dimiliki walaupun berupa sewa ataupun hasilnya seperti dirham (uang) dengan sighat tertentu dalam jangka waktu tertentu sesuai dengan kehendak wakif (Zuhaily, 1981). Ketiga ulama Syafi'iyah wakaf yaitu menahan harta yang dapat dimanfaatkan dengan tetapnya zat benda yang menghalangi waqif dan lainnya dari tindakan hokum yang dibolehkan atau tindakan hokum yang bertujuan untuk kebaikan dan mendeklarasikan diri kepada Allah Ta'ala (Zuhaily, 1981), Keempat, ulama Habilah, asy 
Syaibani dan Abu Yusuf mendefinisikan wakaf adalah menahan harta yang dapat dimanfaatkan dengan tetap zat benda yang menghalangi waqif dan lainnya dari tindakan hokum yang dibolehkan, yang bertujuan untuk kebaikan dalam rangka mendekatkan diri kepada Allah SWT (Zuhaily, 1981). Kelima Wakaf adalah perbuatan hukum wakif untuk memisahkan dan/ atau menyerahkan sebagian harta benda miliknya untuk dimanfaatkan selamanya atau untuk jangka waktu tertentu sesuai dengan kepentingannya guna keperluan ibadah dan/atau kesejahteraan umum menurut syariah (Pasal 1 butir 1 UU No. 41 Tahun 2004 tentang Wakaf).

Dalam Al Quran terdapat beberapa ayat yang didasarkan sebagai landasan perintah wakaf, dalam Quran Surat Al Baqarah ayat 261 yang artinya. Dan ayat Al Quran lain dalam Ali Imran ayat 92. Terdapat empat rukun wakaf yang harus dipenuhi yakni: Pertama, Orang yang berwakaf (al waqif). Kedua, Benda yang diwakafkan (la mauquf). Ketiga, Orang yang menerima wakaf (mauquf alaih). Keempat, Lafaz atau ikrar wakaf.

Dalam undang-undang No. 41 tahun 2004 tentang wakaf terdapat dua tambahan hal yang harus dipenuhi, yaitu peruntukan harta wakaf dan jangka waktu wakaf. Dalam rangka mencapai tujuan dan fungsi wakaf menurut UU No. 41 tahun 2004 tentang wakaf, harta wakaf hanya diinvestasikan hanya diperuntukkan lima macam hal (Hannaf, 2016), yaitu: 1) Sarana dan kegiatan ibadah. 2) Sarana dan kegiatan pendidikan dan kesehatan. 3) Bantuan kepada fakir dan miskin, anak terlantar, yatim piatu, beasiswa. 4) Kemajuan dan peningkatan ekonomi umat, dan/ atau kemajuan kesejahteraan umum yang tidak bertentangan dengan Syariah dan peraturan perundangundangan.

\section{Surat Berharga Syariah Negara (SBSN)}

Pembiayaan APBN dengan menggunakan instrumen utang merupakan hal yang lazim dilakukan dalam pengelolaan keuangan Negara. Dalam APBN, sumber pembiayaan melalui utang dapat diperoleh dari pinjaman luar negeri, pinjaman dalam negeri maupun penerbitan Surat Berharga Negara (SBN). (Direktorat Pembiayaan Syariah Kemenkeu, 2015)

Dalam shari'a standard No. 17 tentang Investment sukuk, AAOIFII (Accounting and Auditing Organization for Islamic Institution) mendefinisikan Sukuk sebagai berikut:

"Investment Sukuk are certificates of equal value representing undivided share in ownership of tangible asets, usufruct and services or (in the ownership of) the asets of particular projects or special investment activity, however, this is true after receipt of the value of sukuk, the closing of subscription and the employment of funds received for the purpose for which the sukuk were issued"

Berdasarkan definisi tersebut di atas dapat disimpulkan bahwa Sukuk adalah sertifikat yang merupakan bukti kepemilikan atas aset berwujud, manfaat atau jasa atau kepemilikan aset suatu proyek atau aktivitas investasi tertentu, yang terjadi setelah penerimaan dana sukuk, penutupan pemesanan dan dana yang diterima dimanfaatkan sesuai tujuan penerbitan sukuk. (Purnamawati, 2012)

Menurut Kemenkeu (2015) Sukuk Negara didefinisikan sebagai Surat Berharga Negara yang diterbitkan berdasarkan prinsip syariah, sebagai bukti atas bagian penyertaan terhadap aset SBSN, baik dalam mata uang rupiah maupun valuta asing. Pengertian tersebut mengacu pada UndangUndang Nomor 19 Tahun 2008 tentang Surat Berharga Syariah Negara.

Sesuai Undang-Undang Nomor 19/2008 tentang Surat Berharga Syariah Negara, Pasal 4, tujuan penerbitan Sukuk Negara adalah untuk membiayai pembangunan APBN termasuk membiayai pembangunan proyek. Penerbitan Sukuk Negara dalam rangka pembiayaan APBN dimaksudkan untuk mengamankan kebutuhan pembiayaan APBN dengan biaya minimal pada tingkat risiko terkendali, sehingga menjaga kesinambungan fiskal. Sedangkan yang dimaksud dengan pembiayaan proyek adalah dalam rangka 
membiayai pembangunan proyek pemerintah yang telah dialokasikan dalam APBN, seperti proyek infrastruktur dalam sektor energi, telekomunikasi, perhubungan, pertanian, industri manufaktur, dan perumahan rakyat.

\section{Manfaat Surat Berharga Syariah Negara (SBSN)}

Berdasarkan Undang-undang Nomor 19/2008 tentang Surat Berharga Syariah Negara pasal 4, Surat Berharga Syariah Negara atau Sukuk Negara memiliki beberapa manfaat bagi bangsa dan negara, antara lain seperti memperluas alternatif sumber pembiayaan APBN, sejalan dengan semakin terbatasnya daya dukung APBN untuk menggerakkan pembangunan sektor ekonomi secara berkesinambungan dan belum optimalnya pemanfaatan instrumen pembiayaan lainya, sehingga diperlukan adanya instrumen pembiayaan lainya seperti Surat Berharga Syariah Negara (SBSN) yang dapat dikeluarkan oleh pemerintah. Selain itu SBSN juga dapat untuk membiayai pembangunan proyek infrastruktur, pembiayaan proyek melalui penerbitan SBSN merupakan salah satu tahapan yang diharapkan dapat menjadi pendorong tercapainya tujuan pembangunan nasional. Pembiayaan Proyek melalui penerbitan SBSN merupakan alternatif sumber pembiayaan APBN yang efektif dan efisien. Penerbitan SBSN untuk pembiayaan Proyek juga dapat meningkatkan kemandirian bangsa dalam melaksanakan pembangunan nasional, karena masyarakat dapat turut langsung berpartisipasi membiayai Proyek Pemerintah melalui pembelian SBSN.

SBSN dapat mengoptimalkan pemanfaatan Barang Milik Negara (BMN), penerbitan Sukuk Negara yang menggunakan underlying aset berupa BMN dapat semakin meningkatkan tertib administrasi pengelolaan BMN, serta mampu mengoptimalkan potensi BMN sebagai dasar penerbitan Sukuk Negara. Dengan adanya sukuk, SBSN mendorong pertumbuhan dan pengembangan pasar keuangan syariah di Indonesia, sukuk diharapkan dapat memenuhi kebutuhan portofolio investasi lembaga keuangan syariah antara lain perbankan syariah, reksadana syariah, dan asuransi syariah. Beberapa manfaat lain dari SBSN yakni; memperkuat dan meningkatkan peran sistem keuangan berbasis syariah di dalam negeri; menciptakan benchmark untuk instrumen keuangan syariah baik di pasar keuangan syariah domestik maupun internasional; memperluas dan mendiversifikasi basis investor; mengembangkan alternatif instrumen investasi, sukuk negara diharapkan dapat menjadi alternatif instrumen investasi syariah di pasar modal dan pasar uang, selain investasi saham, obligasi dan reksadana.

\section{Jenis Instrumen Sukuk Negara}

Pemerintah telah mengembangkan dan menerbitkan enam jenis instrumen SBSN yang ditujukan pada target investor yang bervariasi, baik di pasar keuangan domestik maupun internasional. Keenam jenis sukuk tersebut antara lain: 1) Surat Perbendaharaan Negara-Syariah (SPN-S) merupakan sukuk jangka pendek yang diterbitkan dalam rangka menutupi kekurangan kas jangka pendek akibat ketidaksesuaian antara arus kas penerimaan dan pengeluaran dari rekening kas Negara dalam satu tahun anggaran, tenor SPN-S adalah 6 bulan. 2) Islamic Fixed Rate (IFR) merupakan sukuk dengan akad ijarah sale and lease back dan underlying aset yang digunakan adalah BMN berupa tanah dan bangunan. 3) Project Based Sukuk (PBS) akad yang digunakan pada PBS adalah ijarah aset to be leased dengan underlying aset berupa proyek pemerintah dalam APBN. 4) Sukuk Negara Ritel (SR) menggunakan akad ijarah sale and lease back menggunakan underlying aset berupa tanah dan atau bangunan dan dapat diperdagangkan di pasar sekunder. 5) Sukuk Negara Indonesia (SNI) akad yang digunakan dalam SNI adalah akad wakalah. 6) Sukuk Dana Haji Indonesia merupakan sukuk Negara yang diterbitkan dalam denominasi rupiah untuk penempatan dana haji dan dana abadi umat (Direktorat Pembiayaan Syariah Kemenkeu, 2015). 


\section{SBSN Ijarah Asset to be Leased}

Ijarah adalah akad pemindahan hak guna atas barang dan jasa, tanpa diikuti dengan pemindahan kepemilikan barang atas jasa. Sedangkan akad ijarah asset to be leased didefinisikan sebagai akad yang obyek ijarah-nya sudah ditentukan spesifikasinya, dan sebagian obyek ijarah sudah ada pada saat akad dilakukan, tetapi penyerahan keseluruhan obyekijarah dilakukan pada masayang akan datang sesuai kesepakatan. Pada prinsipnya, akad ini memiliki karakteristik yang hampir sama dengan akad Ijarah Mawsufah fi Dzimmah (Forward Lease), namun dipandang lebih kuat karena sebagian obyek ijarah sudah ada pada saat akad dilakukan, Sukuk Negara yang menggunakan akad tersebut dinamakan SBSN Ijarah Asset to be Leased dan dapat didefinisikan sebagai surat berharga negara yang diterbitkan berdasarkan prinsip syariah, sebagai bukti kepemilikan atas bagian dari aset SBSN yang menjadi obyek ijarah, baik yang sudah ada maupun akan ada (Direktorat Pembiayaan Syariah Kemenkeu, 2015).

SBSN Ijarah Asset to be leased merupakan struktur sukuk baru yang dikembangkan dalam rangka penerbitan sukuk untuk membiayai proyek pemerintah, Sukuk ini dapat dikategorikan ke dalam jenis sukuk yang me-representasikan kepemilikan atas aset berwujud yang dijanjikan akan disewakan (Sukuk Milkiyyah al-Maujudat Al-Mau'ud Bisti'jaraha), sebagaimana mengacu pada AAOIFI Sharia Standars Nomor 17 (13/1). Sukuk ijarah diterbitkan berdasarkan akad ijarah, diklasifikasikan menjadi sukuk kepemilikan aset berwujud yang disewakan, sukuk kepemilikan manfaat, sukuk kepemilikan jasa. Sukuk kepemilikan aset berwujud yang disewakan, diterbitkan oleh pemilik aset yang disewakan atau yang akan disewakan dengan tujuan untuk menjual aset demi memperoleh dana, sehingga pemegang sukuk menjadi pemilik aset. Sedangkan tujuan penerbitan sukuk kepemilikan manfaat, yaitu menyewakan aset/manfaat aset demi uang sewa, pemegang sukuk menjadi pemilik manfaat dari aset. Penerbitan sukuk kepemilikan jasa bertujuan menyediakan jasa melalui penyedia jasa dan mendapatkan fee, sehingga pemegang sukuk menjadi pemilik jasa (Departemen Keuangan Republik Indonesia-Direktorat Pembiayaan Syariah, 2010).

Berdasarkan Bank Indonesia (2016) struktur Surat Berharga Syariah Negara Asset to be Leased adalah sebagai berikut:

\section{a. Penerbitan SBSN:}

1. Pemesanan Obyek Ijarah dengan spesifikasi tertentu oleh Pemerintah kepada Perusahaan Penerbit SBSN (PP SBSN) untuk disewa melalui akad Ijarah Asset to be Leased.

2. Pemberian kuasa (Wakalah Agreement) oleh PP SBSN kepada Pemerintah dalam rangka pembangunan proyek yang akan dijadikan sebagai obyek Ijarah. Pembelian (Akad Bai') tanah dan/atau bangunan yang berupa Barang Milik Negara yang akan dijadikan sebagai bagian obyek Ijarah (dalam hal diperlukan).

3. Penerbitan SBSN oleh PP SBSN sebagai bukti atas bagian penyertaan investor terhadap Aset SBSN.

4. Dana hasil penerbitan SBSN (Proceeds) dari investor kepada PP SBSN.

5. Proceeds dari PP SBSN (Pemberi Kuasa) kepada Pemerintah (Wakil).

\section{b. Pembayaran Imbalan SBSN:}

1. Akad Ijarah Asset to be Leased antara Pemerintah (Penyewa) dengan PP SBSN (Pemberi Sewa).

2. Pembayaran uang sewa (ujrah) secara periodik oleh Pemerintah kepada PP SBSN, untuk diberikan kepada investor sebagai imbalan SBSN.

3. Pembayaran imbalan SBSN secara periodik kepada investor melalui Agen Pembayar.

4. Penandatangan Berita Acara Serah Terima (BAST) proyek antara Pemerintah (wakil) dan PP SBSN (Pemberi Kuasa). 


\section{c. Jatuh Tempo SBSN:}

1. Pembelian Aset SBSN oleh Pemerintah dari pemegang SBSN melalui Perusahaan Penerbit SBSN (Akad Bai') pada saat jatuh tempo.

2. Pembayaran atas pembelian Aset SBSN oleh Pemerintah kepada pemegang SBSN melalui Agen Pembayar sebagai pelunasan SBSN. Jatuh tempo dan Pelunasan SBSN.

Analisis Penganggaran Modal (Capital Budgeting Analysis)

Penganggaran modal (Capital Budgeting) merupakan proses untuk membuat perencanaan jangka panjang dalam suatu proyek investasi (horngren, 2012: 739). Analisis ini membicarakan tentang layak atau tidaknya suatu usulan investasi. Untuk menganalisis suatu usulan investasi hal yang dapat dilakukan yakni: (1) mengestimasi aliran kas bersih yang dihasilkan dari investasi tersebut selama periode yang ditentukan dan (2) mengevaluasi hasil aliran kas tersebut sehingga kita dapat menyimpulkan apakah usulan investasi yang dilakukan layak atau tidak.

\section{Kriteria Penilaian Investasi}

Mamduh M. Hanafi (2016) menjelaskan bahwa dalam menilai suatu kelayakan investasi kriteria yang bisa digunakan adalah Payback Period, Accounting Rate of Return (ARR), Net Present Value (NPV), Internal Rate of Return (IRR) dan Profitability Index (PI). Namun dari seluruh kriteria tersebut hanya metode NPV, IRR, dan PI yang merupakan kriteria terbaik secara teoritis. Hal ini dikarenakan teori tersebutlah yang memperhatikan nilai waktu uang (time value of money), berfokus pada aliran kas dan menggunakan seluruh aliran kas yang tersedia. Secara umum hasil yang dihasilkan dari ketiga kriteria tersebut sama, namun jika bertentangan maka metode NPV merupakan teknik yang seharusnya digunakan.

\section{a. Net Present Value (NPV)}

Net Present Value merupakan nilai preset value dari aliran kas masuk dikurangi dengan present value aliran kas keluar (Hanafi, 2016;
152). NPV menggunakan time value of money dan seluruh aliran kas yang ada dalam suatu proyek investasi. Keputusan investasinya adalah:

NPV $>0$ maka usulan investasi diterima, dan jika NPV $<0$ maka usulan investasi ditolak

\section{b. Internal Rate of Return (IRR)}

IRR merupakan tingkat diskonto (discount rate) yang menyamakan present value aliran kas masuk dengan present value aliran kas keluar (Hanafi, 2016; 153). IRR adalah discount rate yang membuat NPV = 0 dimana PV aliran kas keluar sama dengan aliran kas masuk. Keputusan investasinya adalah:

IRR > tingkat keuntungan yang disyaratkan $\rightarrow$ usulan investasi diterima

IRR < tingkat keuntungan yang disyaratkan $\rightarrow$ usulan investasi ditolak

\section{c. Profitability Index (PI)}

PI merupakan present value aliran kas masuk dibagi dengan present value aliran kas keluar (Hanafi, 2016; 155). PI juga dapat digunakan untuk meranking suatu usulan investasi dalam keadaan keterbatasan modal. Keputusan investasi-nya adalah:

PI $>1$ usulan investasi diterima, dan jika PI $<1$ maka usulan investasi ditolak

\section{Optimalisasi Tanah Aset Wakaf Dengan Skema SBSN}

Sama halnya seperti dalam penerbitan sukuk, sukuk wakaf juga harus memenuhi proses dan syarat yang sama, mulai dari persetujuan (approval), proyek, hingga monitoring. Untuk penerbitan sukuk wakaf dapat dilakukan oleh BUMN, perusahaan swasta, organisasi masyarakat, maupun pemerintah. Bagi sukuk wakaf yang diterbitkan oleh BUMN, nazhir wakaf sebagai pengelola aset wakaf dengan didukung oleh Badan Wakaf Indonesia (BWI) dapat bekerja sama dengan BUMN untuk pemanfaatan aset wakaf sebagai underlying asset sukuk. Setelah mendapat 
persetujuan dari pihak nazhir, objek wakaf lalu daat disewakan ke BUMN. Kemudian sukuk dapat diterbitkan untuk menghimpun dana. Disini peran investor baru mulai masuk. Setelah dihimpun dananya oleh BUMN, kontraktor yang disewa membangun proyek sesuai akad syariah, dimana proyek bersifat produktif yang menghasilkan pendapatan di atas tanah wakaf.

Gambar 3.1 Optimalisasi Tanah Wakaf dengan Skema SBSN

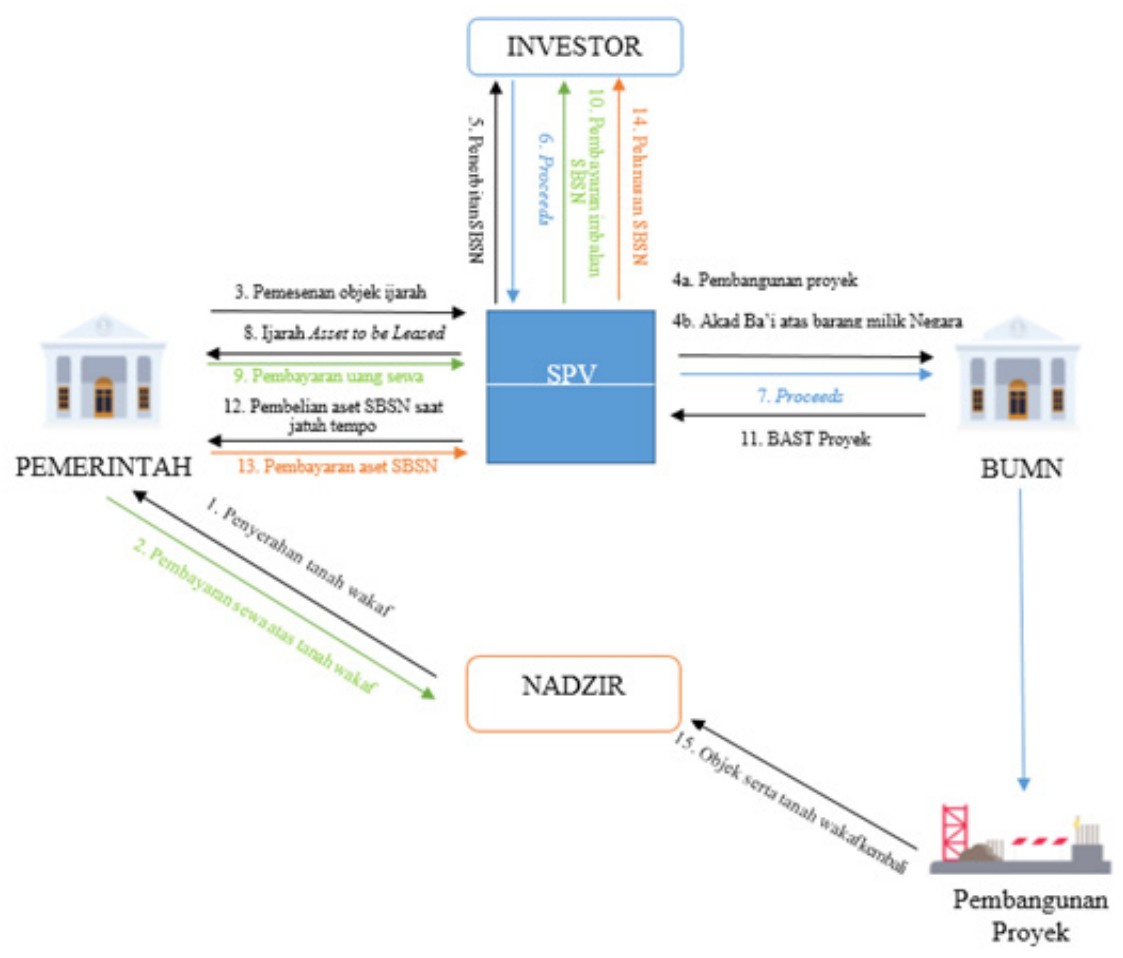

\section{Penerbitan SBSN:}

1. Setelah adanya kesepakatan antara pemerintah dengan pohak nadzhir untuk menyewa tanah wakaf, pihak nadzhir melepas hak pengelolaan kepada pemerintah.

2. Pemerintah membayar uang sewa atas tanah wakaf dimuka dengan jumlah selama 30 tahun.

3. Pemesanan Obyek Ijarah dengan spesifikasi yang telah ditentukan oleh Pemerintah kepada Perusahaan Penerbit SBSN (PP SBSN) untuk disewa melalui akad Ijarah Asset to be Leased.

4. a. Pemberian kuasa (Wakalah Agreement) oleh PP SBSN kepada Pemerintah dalam rangka pembangunan proyek yang akan dijadikan sebagai obyek Ijarah.

b. Pembelian (Akad Bai') tanah dan/atau bangunan yang berupa Barang Milik
Negara yang akan dijadikan sebagai bagian obyek Ijarah (jika diperlukan).

5. Penerbitan SBSN oleh PP SBSN sebagai bukti atas bagian penyertaan investor terhadap Aset SBSN.

6. Dana hasil penerbitan SBSN (Proceeds) dari investor kepada PP SBSN.

7. Proceeds dari PP SBSN (Pemberi Kuasa) kepada Pemerintah (Wakil) yakni BUMN untuk dilakukannya pembangunan proyek diatas tanah wakaf.

\section{Pembayaran Imbalan SBSN:}

8. Akad Ijarah Asset to be Leased antara Pemerintah (Penyewa) dengan PP SBSN (Pemberi Sewa).

9. Pembayaran uang sewa (ujrah) secara periodik oleh Pemerintah kepada PP SBSN, untuk diberikan kepada investor sebagai imbalan SBSN. 
10. Pembayaran imbalan SBSN secara periodik kepada investor.

11. Penandatangan Berita Acara Serah Terima (BAST) proyek antara Pemerintah (wakil) dan PP SBSN (Pemberi Kuasa).

\section{Jatuh Tempo:}

12. Pembelian Aset SBSN oleh Pemerintah dari pemegang SBSN melalui Perusahaan Penerbit SBSN (Akad Bai') pada saat jatuh tempo.

13. Pembayaran atas pembelian Aset SBSN oleh Pemerintah kepada pemegang SBSN melalui Agen Pembayar sebagai pelunasan SBSN.

14. Jatuh tempo dan Pelunasan SBSN.

15. Setelah masa sewa tanah akad selama 30 tahun berakhir, objek akad baik tanah maupun gedung yang berdiri diatasnya kembali kepada pengelolaan pihak nadzhir.

\section{Metodologi Penelitian}

Jenis penelitian yang digunakan adalah penelitian deskriptif dengan pendekatan studi kasus. Penelitian deskriptif yang dimaksud merupakan sebuah konsep pengoptimalisasian tanah wakaf dengan skema penerbitan SBSN melalui penilaian terhadap kelayakan investasi perusahaan milik negara dalam mengoptimalisasikan tanah wakaf. Tujuan dari penelitian ini adalah untuk mempelajari sebuah konsep yang ditawarkan oleh peneliti dalam kasus pemanfaatan tanah wakaf yang lebih produktif dengan adanya kerjasama dari pemerintah/ BUMN. Penelitian deskriptif akan mendapatkan gambaran/skema yang paling memungkinkan dan sesuai dengan ketentuan syariah. Kemudian skema tersebut akan dianalisis dan dinilai agar diperoleh keputusan tepat untuk dilakukan tindakan/penerapan selanjutnya. Penilaian yang dimaksud yakni berkaitan dengan analisis usulan investasi untuk membangun suatu aset usaha yang produktif. Agar dapat melakukan keputusan investasi, beberapa langkah yang dapat dilakukan adalah (Hanafi, 2016; 142): 1) Menaksir aliran kas bersih dari investasi yang akan dilakukan. 2) Menghitung biaya modal rata-rata tertimbang. 3) Mengevaluasi investasi dengan menggunakan kriteria penilaian investasi. 4)Pengambilan keputusan apakah usulan investasi diterima atau tidak.

\section{Pembahasan}

Analisis Penganggaran Modal (Capital Budgeting Analysis) Untuk Skema Pengoptimalisasian Wakaf

\section{Rencana Investasi untuk Pengoptimalisasian Tanah Wakaf}

Pemerintah memiliki pembangunan proyek diatas tanah dengan rincian:

Tabel 1 Estimasi Perencanaan Investasi

\begin{tabular}{|l|r|l|}
\hline Cost sewa & Rp 300.000.000,00 & $\begin{array}{l}\text { diberikan kepada pihak nazhir per } \\
\text { tahun selama 30 tahun dibayar } \\
\text { dimuka }\end{array}$ \\
\hline Cost maintenance & $\mathrm{Rp} \mathrm{150.000.000,00}$ & dibayar per tahun \\
\hline Initial Investment & $\mathrm{Rp} \mathrm{125.450.000.000,00}$ & \\
\hline Sukuk & $\mathrm{Rp} \mathrm{130.000.000.000,00}$ & $\begin{array}{l}\text { jumlah sukuk yang dikeluarkan } \\
\text { pemerintah }\end{array}$ \\
\hline bagi hasil & $\mathrm{Rp} 4.000 .000 .000,00$ & $\begin{array}{l}\text { depresiasi dilakukan dengan metode } \\
\text { garis lurus dan nilai residu 5M } \\
\text { selama 30 tahun }\end{array}$ \\
\hline Depresiasi & $\mathrm{Rp} 12.000 .000 .000,00$ & $\begin{array}{l}\text { per tahun dengan biaya sewa awal } \\
\text { Rp. 10juta dan kenaikan sebesar Rp. } \\
\text { 3juta setiap 3 tahun sekali }\end{array}$ \\
\hline Pendapatan & & \\
\hline
\end{tabular}


Perhitungan biaya modal rata-rata tertimbang menggunakan formula biaya modal utang $(\mathrm{kd})$ karena pendanaan seluruhnya berasal dari dana sukuk (obligasi syariah). Dengan tingkat pajak sebesar 10\%, menghasilkan biaya modal terutang sebesar 7,8\% (lebih tinggi dari BI Rate). Angka ini dipakai sebagai tingkat keuntungan yang disyaratkan (dalam IRR) atau tingkat discount rate (cut-off rate) dalam keputusan penganggaran modal yang akan dihitung dengan metode NPV, IRR, dan PI.

\section{Aliran Kas Bersih}

Hasil dari penaksiran aliran kas bersih (cash inflow) dari estimasi investasi yang dilakukan selama 30 tahun berdasarkan tabel 7.1 yaitu:

Tabel 2 Aliran Kas Bersih (cash inflow) Estimasi Investasi

\begin{tabular}{|c|c|c|c|c|}
\hline Thn & Kas Keluar & Kas Masuk & Aliran Kas Bersih & NPV \\
\hline 0 & 142.970 .000 .000 & 130.000 .000 .000 & $(12.970 .000 .000)$ & $(12.970 .000 .000)$ \\
\hline 1 & 8.970 .000 .000 & 11.065 .000 .000 & 2.095 .000 .000 & 1.943 .413 .729 \\
\hline 2 & 8.970 .000 .000 & 11.065 .000 .000 & 2.095 .000 .000 & 1.802 .795 .667 \\
\hline 3 & 8.970 .000 .000 & 11.065 .000 .000 & 2.095 .000 .000 & 1.672 .352 .196 \\
\hline 4 & 138.970 .000 .000 & 14.305 .000 .000 & $(124.665 .000 .000)$ & $(92.314 .409 .913)$ \\
\hline 5 & + & 14.305 .000 .000 & 14.305 .000 .000 & 9.826 .391 .381 \\
\hline 6 & - & 14.305 .000 .000 & 14.305 .000 .000 & 9.115 .390 .891 \\
\hline 7 & - & 17.545 .000 .000 & 17.545 .000 .000 & 10.371 .033 .727 \\
\hline 8 & - & 17.545 .000 .000 & 17.545 .000 .000 & 9.620 .624 .978 \\
\hline 9 & - & 17.545 .000 .000 & 17.545 .000 .000 & 8.924 .512 .967 \\
\hline 10 & - & 20.785 .000 .000 & 20.785 .000 .000 & 9.807 .592 .669 \\
\hline 11 & - & 20.785 .000 .000 & 20.785 .000 .000 & 9.097 .952 .383 \\
\hline 12 & - & 20.785 .000 .000 & 20.785 .000 .000 & 8.439 .658 .982 \\
\hline 13 & - & 24.025 .000 .000 & 24.025 .000 .000 & 9.049 .394 .166 \\
\hline 14 & - & 24.025 .000 .000 & 24.025 .000 .000 & 8.394 .614 .255 \\
\hline 15 & - & 24.025 .000 .000 & 24.025 .000 .000 & 7.787 .211 .739 \\
\hline 16 & - & 27.265 .000 .000 & 27.265 .000 .000 & 8.197 .951 .193 \\
\hline 17 & - & 27.265 .000 .000 & 27.265 .000 .000 & 7.604 .778 .473 \\
\hline 18 & - & 27.265 .000 .000 & 27.265 .000 .000 & 7.054 .525 .485 \\
\hline 19 & - & 30.505 .000 .000 & 30.505 .000 .000 & 7.321 .744 .559 \\
\hline 20 & - & 30.505 .000 .000 & 30.505 .000 .000 & 6.791 .970 .834 \\
\hline 21 & - & 30.505 .000 .000 & 30.505 .000 .000 & 6.300 .529 .531 \\
\hline 22 & - & 33.745 .000 .000 & 33.745 .000 .000 & 6.465 .419 .277 \\
\hline 23 & - & 33.745 .000 .000 & 33.745 .000 .000 & 5.997 .606 .008 \\
\hline 24 & - & 33.745 .000 .000 & 33.745 .000 .000 & 5.563 .641 .937 \\
\hline 25 & - & 36.985 .000 .000 & 36.985 .000 .000 & 5.656 .614 .752 \\
\hline 26 & - & 36.985 .000 .000 & 36.985 .000 .000 & 5.247 .323 .517 \\
\hline 27 & - & 36.985 .000 .000 & 36.985 .000 .000 & 4.867 .647 .048 \\
\hline 28 & - & 40.225 .000 .000 & 40.225 .000 .000 & 4.911 .009 .214 \\
\hline 29 & - & 40.225 .000 .000 & 40.225 .000 .000 & 4.555 .667 .174 \\
\hline 30 & - & 40.225 .000 .000 & 40.225 .000 .000 & 4.226 .036 .340 \\
\hline
\end{tabular}


Dari hasil perhitungan di tabel 3.2 menunjukkan bahwa dengan menggunakan aliran kas bersih(Payback Periode), modal akan kembali di tahun ke-12 dengan menyisakan kelebihan sebesar Rp. 3.715.000,-di tahun ke-12. Artinya butuh waktu selama 11,3 tahun untuk pemerintah agar modal yang dikeluarkan bisa kembali. Sehingga total keuntungan yang didapat selama 30 tahun adalah sebesar Rp. 590.500.000.000,- dari aliran kas bersih.

\section{Analisis Capital Budgetingdari Aliran Kas Bersih yang Diterima}

a. Dari hasil perhitungan diatas, total NPV yang didapat selama 30 tahun yakni sebesar 91.330.995.159. Maka NPV > 0 sehingga usulan investasi diterima dan layak dilakukan. Dari hasil NPV tersebut kita dapat menyimpulkan bahwa dengan total keuntungan yang didapat di 30 tahun mendatang (Rp. 590.500.000.000,-) maka nilainya sama dengan Rp. 91.330.995.159,- di masa sekarang karena nilai tersebut sudah di present value kan.

b. $\quad$ IRR $=14,58 \%$. Dimana IRR > daripada tingkat keuntungan yang disyaratkan (7,8\%). Hal tersebut menunjukkan bahwa usulan investasi diterima dan layak untuk dilakukan.

c. $\mathrm{PI}=1,867$ dimana $\mathrm{PI}>1$ sehingga dapat dikatakan bahwa usulan investasi diterima.

Dari ketiga kriteria tersebut dapat disimpulkan bahwa investasi untuk pembangunan aset diatas tanah wakaf layak dilakukan. Hal ini ditunjukan dari perhitungan dengan ketiga kriteria analisis kelayakan modal tersebut.

\section{Manfaat Sukuk BUMN Berbasis Wakaf}

1. Bagi pihak Nazhir:

Manfaat yang diadapatkan bagi pihak nazhir (termasuk BWI) antara lain mendapatkan pendapatan sewa. Dengan pendapatan tersebut Nazhir bisa memproduktifkan aset wakaf yang lain sehingga dapat menghasilkan pengoptimalisasian tanah wakaf yang baru untuk kesejahteraan umat. Pendapatan sewa yang didapat nazhir dari tabel 3.1 yakni sebesar Rp. 9.000.000.000(selama 30 tahun) dimana pendapatan tersebut diterima diawal kesepakatan. Dari dana tersebut pihak nazhir memiliki beberapa opsi yakni:

a. Dana tersebut dapat dialokasikan untuk mensejahterakan umat sekitar seperti untuk pembangunan fasilitas umum, masjid, jalan atau pengalokasian dana yang bersifat konsumtif lainnya. Tentu saja hal tersebut didasarkan untuk kepentingan bersama.

b. Pihak nazhir juga dapat mendirikan suatu usaha baru yang bersifat produktif. Mereka dapat membentuk suatu cv atau firma yang bergerak dalam perusahaan dagang, jasa ataupun manufaktur. Tentunya dari suatu pembukaan lapangan kerja yang baru akan menyerap lebih banyak tenaga kerja lagi dari masyarakat. Sehingga pengalokasian dana tersebut akan lebih maksimal dan cenderung akan bertambah.

c. Opsi lainnya yakni nazhir dapat mengalokasikan dana tersebut untuk membantu modal/ keuangan umkm masyarakat sekitar dengan menerbitkan suatu pembiayaan. Pembiayaan yang dimaksud dapat berupa pinjaman dengan menggunakan akad qardh. Disini pihak nazhir dapat berperan sebagai lembaga keuangan non bank karena menyalurkan dana kepada masyarakat yang membutuhkan.

d. Opsi terakhir yakni nazhir dapat menginvestasikan beberapadaripengalokasian dananya untuk proyek pemerintah lainnya.

Selain manfaat diatas, nadzhir juga akan mendapatkan realisasi pembangunan aset pada saat masa kontrak habis (setelah 30 tahun). Skema perpindahan kepemilikan aset dapat digambarkan sebagai berikut: 


\section{Gambar 3.2 Skema Perpindahan Aset dan Tanah Wakaf}

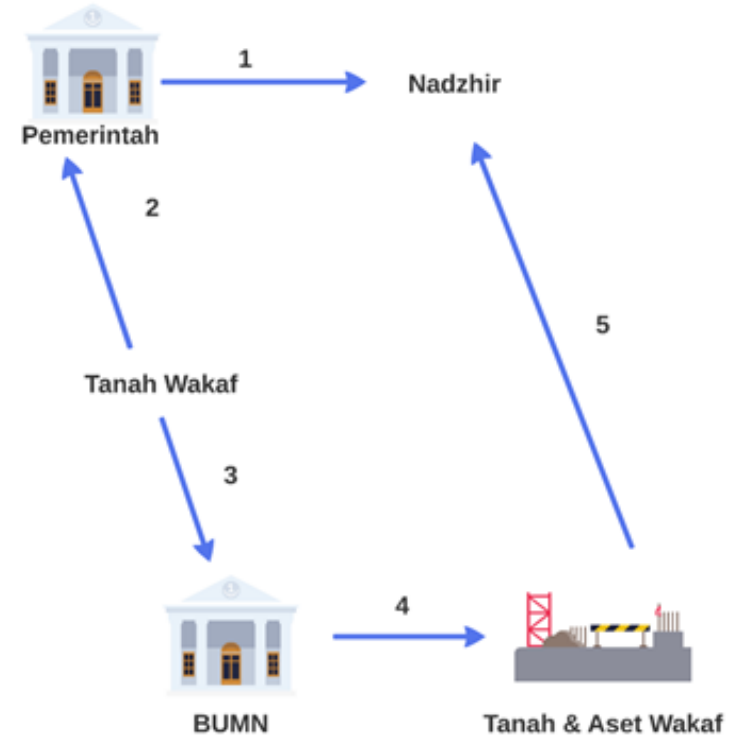

\section{Keterangan:}

1. Pemerintah menawarkan kepada Nazhir untuk menyewa aset wakaf dengan skema yang sudah dijelaskan sebelumnya.

2. Ketika pihak nazhir menyetujui untuk menyewakan tanah wakaf kepada pemerintah, kemudian nazhir menyerahkan hak pengelolaan tanah wakaf kepada pemerintah dengan kontrak sewa serta pendapatan yang diterima dimuka.

3. Setelah SBSN diterbitkan (proceeds), BUMN mengambil alih pembangunan aset dengan akad ijara' asset to be leased.

4. Setelah aset sudah jadi (berupa gedung/ bangunan diatas tanah wakaf), pihak-pihak maupun perusahaan yang memiliki usaha diatas tanah wakaf tersebutharus membayar pendapataan sewanya kepada BUMN.

5. Dengan menggunakan skema sebelumnya, setelah 30 tahun pemerintah/BUMN harus mengembalikan tanah wakaf yang disewa beserta aset kepada pihak nazhir sesuai kontrak. Barang/aset yang diserahkan kembali kepada nazhir dapat disesuaikan pada kontrak yang dibuat sebelumnya. Setelah aset kembali kepada nazhir, perusahaan yang tetap beroperasi diatas tanah wakaf sudah tidak membayar sewanya lagi kepada pemerintah melainkan kepada nazhir. Atau jika kontrak perusahaan-perusahaan tersebut selesai dan nazhir hanya menerima aset dan bangunan saja maka nazhir dapat memanfaatkan kembali aset tersebut untuk usaha/kebutuhan lainnya.

\section{Bagi pihak BUMN:}

Kementerian BUMN juga mendapatkan keuntungan dari penerbitan sukuk karena bisa diperdagangkan, mendapatkan porsi imbalan dari proceeds project, dan berperan sebagai market maker. Sementara, bagi BI dan Kementerian Keuangan bisa mendukung program-program sosial pemerintah, serta memperdalam pasar keuangan syariah. Keuntungan yang diperoleh oleh pihak BUMN yakni sebesar Rp. 590.500.000.000,(Tabel 3.2). Selain dari sisi ekonomis, pihak pemerintah juga dapat sekaligus mengenalkan dan mengedukasikan produk sukuk kepada masyarakat maupun investor sehingga mereka tidak hanya menggunakan produk pendanaan yang ada di perbankan maupun pasar saham saja tetapi juga mulai menggunakan sukuk sebagai media investasinya. Karena sukuk memiliki nilai lebih daripada produk pendanaan lainnya yakni dijamin oleh pemerintah atas dana yang mereka miliki sehingga resikonya adalah 0 (zero risk). 
3. Bagi Masyarakat:

Manfaat bagi masyarakat yakni adanya proyek sosial yang dibangun, mendorong produksi serta mendapat manfaat langsung dan tidak langsung untuk kegiatan ekonomi dan sosial. Selain itu dengan adanya aset yang dibangun diatas tanah wakaf akan menambah jumlah lapangan kerja sehingga akan menyerap tenaga kerja masyarakat.

\section{Bagi Investor:}

Untuk para investor manfaat yang didapat selain mendapat fee bagi hasil yakni adalah adanya jaminan dari pemerintah. Faktor resiko yang didapat investor hampir mendekati nol (zero risk) karena surat utang dikeluarkan oleh pemerintah. Investor akan mendapat manfaat tambahan selain fee bagi hasil jika nantinya sukuk yang dijual dihargai lebih besar daripada harga belinya (capital gain).

\section{Kekurangan dan Risiko}

Selain memiliki manfaat bagi berbagai pihak, pada praktiknya pengoptimalisasian tanah wakaf ini juga memiliki beberapa kekurangan baik dari hasil analisis maupun dari skema penerbitan SBSN oleh BUMN.

1. Karena tujuan pembangunan aset adalah untuk usaha yang bersifat produktif, maka letak/posisi tanah wakaf haruslah strategis. Pemerintah juga harus meninjau lokasi tanah wakaf terutama dari tingkat konsumsi masyarakat disekitarnya.

2. Risiko selanjutnya yakni jika ditengah-tengah usaha tiba-tiba perusahaan bangkrut atau tidak laku. Bagi pihak nadzhir tidak perlu khawatir sebab mereka telah mendapatkan penghasilan sewa selama masa kontrak.

3. Kekurangan dari hasil analisis yakni terletak pada saat penjualan kembali sukuk yang dimiliki investor. Harga jual sukuk tidak di present value-kan secara terpisah karena sudah dimasukan kedalam aliran kas bersihnya. Selain itu hasil analisis juga menggunakan asumsi bahwa harga beli sama dengan harga jual sukuk di tahun ke 5 .
4. Keprofesionalitasan dari pihak nadzhir dibutuhkan untuk mengelola dana yang didapat maupun aset wakaf yang akan kembali setelah masa sewa berakhir. Dari pendapatan sewa nadzhir mendapat dana sebesar Rp. 9.000.000.000. Disini nadzhir dituntut profesional dalam menggunakan dana yang didapat. Pihak nadzhir harus dapat mengelola dengan baik seluruh dana yang didapat agar bisa digunakan bagi kemaslahatan umat. Jangan sampai terjadi kecurangan maupun penggelapan dana dalam pengelolaan dana yang didapat dari tanah wakaf.

\section{Kesimpulan}

Beberapa kesimpulan dan saran yang didapat dari konsep dan hasil analisis diatas yakni:

1. Untuk mengoptimalisasikan tanah wakaf, nazhir (bersama BWI) dapat bekerja sama dengan pemerintah dan BUMN untuk membangun suatu aset produktif dengan menggunakan akad Ijara'aset to be leased. Dimana setelah jangka waktu perjanjian telah selesai baik aset bangunan dan tanah wakaf akan kembali kepada pengelolaan pihak nazhir.

2. Setelah dilakukan analisis dengan 3 kriteria kelayakan investasi, seluruh kriteria mendukung bahwa usulan investasi diterima. Inimenandakanbahwapemerintahsebenarnya sangat layak untuk menginvestasikan dana mereka di tanah wakaf selain untuk mendapat pemasukan kedalam APBN, pemerintah juga dapat mengatasi kesenjangan sosial yakni mengatasi pengangguran di Indonesia karena pembangunan infrastruktur pasti menyerap banyak tenaga kerja yang terlibat didalamnya.

3. Banyak manfaat yang diterima dari penerapan konsep pengoptimalisasian tanah wakaf diatas baik dari pihak pemerintah/ BUMN, pihak nazhir, masyarakat maupun investor. Terutama dari pihak nazhir dimana selain mendapat keuntungan pengelolaan dan pembangunan ditanah wakaf, mereka 
juga mendapat keuntungan finansial dari penyewaan tanah wakaf. Dari dana ini nazhir dapat mengekspansi kegiatan maupun pembangunan diatas tanah wakaf lain untuk kepentingan dan kemajuan umat/masyarakat sekitar.

\section{Daftar Pustaka}

AAOIFI (Accounting and Auditing Organization for Islamic Institution Standard) No. 17 UU.

No. 19/2008 Tentang Surat Berharga Syariah Negara Pasal 4

Ainaini, Badran Abu al-, Ahkam al-Washy wa Auqaf, Iskandariyah: Muassasat as-Salaby, t.t

Anshori, Abdul Ghofur. 2006, Hukum dan Pratik Perwakafan di Indonesia, Pilar Media, Yogyakarta

Anshari, Ibn Manzur Jamal al-Din Muhammad ibn Mukarram al-, Lisan al-Arab, t.p. Dar alMa'arif, tt

Dahlan, Moo. 2009. Abdullah Ahmed an-Na'im: Epistemologi Hukum Islam, Pustaka Pelajar, Yogyakarta

Departemen Keuangan Republik IndonesiaDirektorat Pembiayaan Syariah. 2010. Surat Berharga Syariah Negara (Sukuk Negara) Instrumen Keuangan Berbasis Syariah. Kementrian Keuangan. Jakarta

Direktorat Pembiayaan Syariah-Kementrian Keuangan. 2015. Sukuk Negara Instrumen Keuangan Berbasis Syariah. Kementrian Keuangan. Jakarta

Esposito, Jhon C. 2001. Ensiklopedi Oxford Dunia Islam Modern Jilid 6. Jakarta: Mizan

Hanafi, Hamduh M. 2016. Manajemen Keuangan. Yogyakarta: BPFE
Hongren, Charles T, Sirkant M Datar, Madhav V Rajan. 2012. Cost Accounting: A Managerial Emphasis 14th Edition. New York; Prentice Hall

Huda, Nurul dan Mustafa Edwin Nasution, Investasi pada Pasar Modal Syariah, Jakarta: Kencana Pranada Media Group, 2007

Mundzir, Qahaaf. 2005. Manajemen Wakaf Produktif. Jakarta Penerbit Khalifa

Nafis, H.M Cholil. 2010. Peluang Kemitraan Investasi Wakaf Produktif

Nasution, Edwin M \& Hasanah U. 2005. Wakaf Tunai Inovasi Finansial Islam Peluang dan Tantangan dalam Mewujudkan Kesejahteraan Umat. PSTTI-UI

Nazaruddin, Abdul Majid. 2008,Sukuk Memahami \&Membedah Obligasi pada Perusahaan Otoritas Jasa Keuangan. Jakarta: Rajawali Pers

Purnawati, Indah. 2012. Perbandingan Sukuk dan Obligasi (Telaah dari Perspektif Keuangan dan Akuntansi). Jurnal Akuntansi Universitas Jember

Trisilo, Rudi Bambang. 2014. Penerapan Akad pada Obligasi Syariah dan Sukuk Negara (SBSN). Jurnal Ekonomi dan Hukum Islam: Vol. 4, No. 1

Wadjdy,Farid.,Mursyid. 2007. Wakaf dan Kesejahteraan Umat: Filantropi Islam yang Hampir Terlupakan. Yogyakarta: Penerbit Pustaka Pelajar

Wahid, Nazaruddin Abdul. 2010,Sukuk: Memahamidan Membedah Obligasi pada Perbankan Syariah., Jakarta: ArRuzz Media Yaumudin, UmiKaromah. 2008, Sukuk: SebuahAlternatifInstrumenInvestasi. Yogyakarta: Kreasi Wacana

Zuhaily, Wahbah az-, Al-Fikih al-Islamy wa Adillatuh, Beirut: Dar al-Fikri, 1981. 


\section{Lampiran}

Ilustrasi perhitungan aliran kas usulan investasi Perhitungan Kas Operasional

\begin{tabular}{|l|r|r|}
\hline & Laporan Laba-Rugi & Aliran Kas \\
\hline Penjualan & $\mathrm{Rp} 12.000 .000 .000$ & $\mathrm{Rp} 12.000 .000 .000$ \\
\hline Biaya Operasional & $\mathrm{Rp} 150.000 .000$ & $\mathrm{Rp} 150.000 .000$ \\
\hline Depresiasi & $\mathrm{Rp} 4.000 .000 .000$ & \\
\hline Laba Operasional & $\mathrm{Rp} 7.850 .000 .000$ & \\
\hline Pajak (10\%) & $\mathrm{Rp} 785.000 .000$ & $\mathrm{Rp} 785.000 .000$ \\
\hline Laba Bersih & $\mathrm{Rp} 7.065 .000 .000$ & $\mathrm{Rp} 11.065 .000 .000$ \\
\hline
\end{tabular}

Aliran Kas $=$ Laba bersih + depresiasi

$$
\begin{aligned}
& =7.065 .000 .000+4.000 .000 .000 \\
& =11.065 .000 .000
\end{aligned}
$$

\begin{tabular}{|c|c|c|c|c|c|c|c|}
\hline $\begin{array}{c}\text { Item Aliran } \\
\text { Kas }\end{array}$ & Tahun 0 & Tahun 1 & Tahun 2 & Tahun 3 & Tahun 4 & Tahun 5 & Tahun 30 \\
\hline \multicolumn{8}{|l|}{$\begin{array}{l}\text { Aliran Kas } \\
\text { Keluar }\end{array}$} \\
\hline $\begin{array}{l}\text { Cost } \\
\text { Pembangunan } \\
\text { Aset }\end{array}$ & 125.000 .000 .000 & & & & & & \\
\hline $\begin{array}{l}\text { Cost Sewa (30 } \\
\text { tahun) }\end{array}$ & 9.000 .000 .000 & & & & & & \\
\hline Fee Investor & 8.970 .000 .000 & 8.970 .000 .000 & 8.970 .000 .000 & 8.970 .000 .000 & .970 .000 .000 & - & \\
\hline $\begin{array}{l}\text { Kupon } \\
\text { Investor }\end{array}$ & & & & & 130.000 .000 .000 & - & \\
\hline $\begin{array}{l}\text { Total Kas } \\
\text { Keluar }\end{array}$ & 142.970 .000 .000 & 8.970 .000 .000 & 8.970 .000 .000 & 8.970 .000 .000 & 138.970 .000 .000 & & \\
\hline \multicolumn{8}{|l|}{$\begin{array}{l}\text { Aliran Kas } \\
\text { Masuk }\end{array}$} \\
\hline $\begin{array}{l}\text { Pemasukan } \\
\text { sukuk }\end{array}$ & 130.000 .000 .000 & & & & & & \\
\hline $\begin{array}{l}\text { Kas Masuk } \\
\text { Operasional }\end{array}$ & & 11.065 .000 .000 & 11.065 .000 .000 & 11.065 .000 .000 & 14.305 .000 .000 & 14.305 .000 .000 & 14.305 .000 .000 \\
\hline $\begin{array}{l}\text { Total Kas } \\
\text { Masuk }\end{array}$ & 130.000 .000 .000 & 11.065 .000 .000 & 11.065 .000 .000 & 11.065 .000 .000 & 14.305 .000 .000 & 14.305 .000 .000 & 14.305 .000 .000 \\
\hline $\begin{array}{l}\text { Aliran Kas } \\
\text { Bersih }\end{array}$ & $(12.970 .000 .000)$ & 2.095 .000 .000 & 2.095 .000 .000 & 2.095 .000 .000 & $(124.665 .000 .000)$ & 14.305 .000 .000 & 14.305 .000 .000 \\
\hline
\end{tabular}


Hasil Perhitungan cash inflow selama 30 tahun

\begin{tabular}{|c|c|c|c|c|}
\hline Thn & Kas Keluar & Kas Masuk & Aliran Kas Bersih & NPV \\
\hline 0 & 142.970 .000 .000 & 130.000 .000 .000 & $(12.970 .000 .000)$ & $(12.970 .000 .000)$ \\
\hline 1 & 8.970 .000 .000 & 11.065 .000 .000 & 2.095 .000 .000 & 1.943 .413 .729 \\
\hline 2 & 8.970 .000 .000 & 11.065 .000 .000 & 2.095 .000 .000 & 1.802 .795 .667 \\
\hline 3 & 8.970 .000 .000 & 11.065 .000 .000 & 2.095 .000 .000 & 1.672 .352 .196 \\
\hline 4 & 138.970 .000 .000 & 14.305 .000 .000 & $(124.665 .000 .000)$ & $(92.314 .409 .913)$ \\
\hline 5 & & 14.305 .000 .000 & 14.305 .000 .000 & 9.826 .391 .381 \\
\hline 6 & & 14.305 .000 .000 & 14.305 .000 .000 & 9.115 .390 .891 \\
\hline 7 & & 17.545 .000 .000 & 17.545 .000 .000 & 10.371 .033 .727 \\
\hline 8 & & 17.545 .000 .000 & 17.545 .000 .000 & 9.620 .624 .978 \\
\hline 9 & & 17.545 .000 .000 & 17.545 .000 .000 & 8.924 .512 .967 \\
\hline 10 & & 20.785 .000 .000 & 20.785 .000 .000 & 9.807 .592 .669 \\
\hline 11 & & 20.785 .000 .000 & 20.785 .000 .000 & 9.097 .952 .383 \\
\hline 12 & & 20.785 .000 .000 & 20.785 .000 .000 & 8.439 .658 .982 \\
\hline 13 & & 24.025 .000 .000 & 24.025 .000 .000 & 9.049 .394 .166 \\
\hline 14 & & 24.025 .000 .000 & 24.025 .000 .000 & 8.394 .614 .255 \\
\hline 15 & & 24.025 .000 .000 & 24.025 .000 .000 & 7.787 .211 .739 \\
\hline 16 & & 27.265 .000 .000 & 27.265 .000 .000 & 8.197 .951 .193 \\
\hline 17 & & 27.265 .000 .000 & 27.265 .000 .000 & 7.604 .778 .473 \\
\hline 18 & & 27.265 .000 .000 & 27.265 .000 .000 & 7.054 .525 .485 \\
\hline 19 & - & 30.505 .000 .000 & 30.505 .000 .000 & 7.321 .744 .559 \\
\hline 20 & & 30.505 .000 .000 & 30.505 .000 .000 & 6.791 .970 .834 \\
\hline 21 & & 30.505 .000 .000 & 30.505 .000 .000 & 6.300 .529 .531 \\
\hline 22 & - & 33.745 .000 .000 & 33.745 .000 .000 & 6.465 .419 .277 \\
\hline 23 & & 33.745 .000 .000 & 33.745 .000 .000 & 5.997 .606 .008 \\
\hline 24 & & 33.745 .000 .000 & 33.745 .000 .000 & 5.563 .641 .937 \\
\hline 25 & & 36.985 .000 .000 & 36.985 .000 .000 & 5.656 .614 .752 \\
\hline 26 & - & 36.985 .000 .000 & 36.985 .000 .000 & 5.247 .323 .517 \\
\hline 27 & - & 36.985 .000 .000 & 36.985 .000 .000 & 4.867 .647 .048 \\
\hline 28 & & 40.225 .000 .000 & 40.225 .000 .000 & 4.911 .009 .214 \\
\hline 29 & & 40.225 .000 .000 & 40.225 .000 .000 & 4.555 .667 .174 \\
\hline 30 & & 40.225 .000 .000 & 40.225 .000 .000 & 4.226 .036 .340 \\
\hline
\end{tabular}

Perhitungan Biaya Modal Terutang:

\begin{tabular}{|l|l|l|l|l|l|l|l|}
\hline $\begin{array}{l}\text { Biaya modal } \\
\text { terutang= }\end{array}$ & 4.655 .000 & 317509,3 & 292209,1 & 268925,0 & 247496,2 & 227774,9 & 3301085,489 \\
\hline & $\begin{array}{l}\text { Total } \\
\text { dengan kd: } \\
8,66 \%\end{array}$ & 4.655 .000 & & & & & \\
\hline
\end{tabular}

kd PV Masuk PV Keluar Jumlah

$8,66 \% \quad 4.655 .000(4.655 .000) \quad 0,$,00 . 
Biaya Modal Terutang setelah pajak:

$=\mathrm{kd}(1$-tingkat pajak)

$=8,6 \%(1-0,01)$

$=7,8 \%$

Perhitungan IRR dengan menggunakan Excel

\begin{tabular}{|c|c|c|r|}
\hline IRR: & & & \\
\hline Discount Rate & PV Kas Masuk & PV Kas Keluar & NPV \\
\hline $14,5754139601624 \%$ & 85.310 .049 .446 & $(85.310 .049 .446)$ & 0,000 \\
\hline $7,8 \%$ & 196.615 .405 .072 & $(105.284 .409 .913)$ & 91330995159 \\
\hline
\end{tabular}

Perhitungan PI

PI: $\frac{(\text { PV Kas Masuk) }}{(\text { PV Kas Keluar })}=\frac{(196.615 .405 .072)}{(105.284 .409 .913)}=1,867$

